\title{
ДОКУМЕНТИ
}

\section{ПІДПІЛЬНА ЦЕРКВА У ВИМІРІ ЛОКАЛЬНОЇ ІСТОРІЇ. АРЕШТ РОДИНИ СВЯЩЕНИКА АНТІНА СІРЕЦЬКОГО}

\author{
ОКсаНа СІРЕЦЬКА (ЗАТОРСЬКА) \\ вул. Карпатська 6. кв. 38, 03087, \\ Івано-Франківськ, Україна, \\ e-mail: siroksana@ukr.net \\ DOI: 10.15330/gal.33.177-181 \\ ORCID: 0000-0002-6286-538X \\ Олег СГРЕШІЙ \\ Державний вищий навчальний заклад \\ "Прикарпатський національний університет імені Василя Стефаника", \\ кафедра історії України і методики викладання історії, \\ вул. Шевченка, 57, 76018, Івано-Франківськ, Україна \\ e-mail:ludyna@ukr.net \\ DOI: 10.15330/gal.33.177-181 \\ ORCID: 0000-0002-0639-910X
}

Минулого, 2019 р. виповнилося 30 років із часу виходу Української греко-католицької Церкви (УГКЦ) з підпілля, що, своєю чергою, спонукає до відповідних осмислень (чи то переосмислень) зазначеної події дослідниками. На наш погляд, в умовах нинішньої прагматичноринкової доби з ії вираженою іррелігійністю, вивчення повсякденного життя греко-католицьких священиків "катакомбної” доби набуває особливого сенсу. Задане історичне минуле показує, що в умовах якраз таких “пограничних ситуацій” і перевіряється справжня жива віра в Бога, уповання на Всевишнього, коли християнин поставлений ніби віч-на-віч із випробовуванням.

Одразу ж постає резонне питання - способи вивчення повсякденного життя священиків підпільної Церкви. Очевидно, в силу заангажованості періодичних видань та архівних матеріалів першорядними пам'ятками тут постають джерела епістолярного напряму, бо це особливий вид першоджерел, який дає спромогу “побачити досі не побачене”, адже почерк, “архаїка висловлювань", дубляж слів, виставлення лапок, авторські виправлення, вживання латинізмів, запозичення термінів з інших наук часом говорять про автора, його внутрішній світ більше аніж, власне, сам зміст листів, його тематичне навантаження.

Уважаємо, що історія повсякденності, як окремий напрям в науці є максимально наближена до вирішення важливих проблем сучасності, адже безпосереднім предметом їі дослідження постає якраз конкретна людина у широкому іiї пізнавальному вимірі з ії неповторним внутрішнім світом, зовнішнім середовищем (соціальним антуражем), побутом, ціннісними характеристиками, зацікавленнями, контактами з іншими людьми, виживанням в умовах різних історичних часових відтинків. Відома українська дослідниця історії повсякденності, вінничанка Ольга Коляструк відзначає репрезентативність першоджерел цього історичного напряму. Такі першоджерела, на їі думку, мають “спонтанний” характер, довільне формулювання та виразно суб' єктивне забарвлення. “Его-документи” (щоденники, листи, нотатки для пам'яті) створені суголосно настрою автора, відповідно до його оптики бачення подій. Як уважає дослідниця, міра узагальнень, припустимих екстраполяцій на підставі цих свідчень, має грунтуватися не тільки на чисельно представницькому масиві, а й на зваженості контекстного співвідношення приватного і суспільного, одиничного і множинного ${ }^{1}$.

\footnotetext{
${ }^{1}$ Коляструк О. Документи особового походження як джерела з історії повсякденності. Украӥнський історичний журнал. 2008. № 2. С. 145.
} 
За приватними спостереженнями і зауваженнями, вважає О. Коляструк, ховається не тільки індивідуально-персоналізований зріз часу, а й відбиток громадського смаку в широкому розумінні. Головне і другорядне поміняні місцями, чого в офіційних документах не допускається: “нерідко у мимохідь кинутих висловах чи фразах можна вловити найточнішу оцінку досліджуваного, коли неочікувана фіксація випадковості віддзеркалює закономірність, а підкреслена - виключність відтісняє типовість явища. Погляд пересічної людини, людини "із натовпу”, “із середовища" вихоплює із життя такі факти, які з офіційних позицій не помічаються, а тому не беруться до уваги при аналізі”"2.

У листах натрапляємо на свідчення особисте, “зсередини", найменш підвладне кон'юнктурі і диктатові ситуації, вільне від цензури. Жоден офіційний документ, з якою б акуратністю і старанністю він не складався, не відтворить справжніх переживань, настроїв, оригінальних оцінок, сумнівів чи вагань. Саме у конфіденційних документах люди фіксують свої рішення, незгоду, а іноді й потаємні гадки. У листах “проговорюється” епоха, їі специфіка3․

Пропонований лист - мізерна частинка епістолярної спадщини родини підпільного греко-католицького священика Антіна Сірецького. Листування дивом збереглося з далеких 1950-х і розказує нащадкам про побут сім'ї священика за складних суспільно-політичних умов радянського тоталітаризму. Епістолярій, що зберігся на 80\% відбиває листування Антіна Сірецького 3 молодшим сином Ярославом. Меншою мірою це стосується представників далекої родини і сусідів (до депортації родина проживала у с. Молодятин на Коломийщині).

Лист друкується вперше і розкриває маловідомі обставини перебування родини Сірецьких у Коломийській в’язниці (березень-квітень 1950 р.) перед депортацією у Хабаровський край.

3 метою точної регенерації (відтворення) листа, нами залишено його автентику, включно 3 авторськими “галицизмами”, скороченнями, філологічними похибками, великими літерами, підкресленнями, знаками оклику / запитання, усталеним на той час правописом, авторським стилем тощо. Разом із тим, розпізнавати скорочення у листі нерідко видавалося “справою не 3 легких". Пояснюємо це тим, що автор листа Антін Сірецький нерідко не ризикував говорити відкритим текстом навіть 3 найріднішими людьми, очевидно боявся аби лист не потрапив до чужих рук. Задля кращого тлумачення листа в округлих дужках ми подекуди роз'яснювали окремі його уступи.

\section{Арк. 1}

Коломия ул. Кирова. Тюрма № 2 Сірецькій Софії Володимирівні Нижній Вербіж

Дорогі! Коломия 10 квітня 1950 р.

Чуємо, що можна написати до Вас то користаємо з того, може дістанете. Ми всі здорові та як маєтеся? Коби і Вам можна написати! Але чи маєте на чім? На кожній заяві до передачі питаємо чи Вам чого спеціально не треба, щоби передати бо може тут не приходить на думку. Але тих заяв тепер не звертають тож нічого не знаємо. Пес дуже тужить за вами. Пару днів був у Печеніжині, одну ніч переночував у Юльці тай втік назад до Молодятина. Вас дуже щиро поздоровляє вся родина. Ольдзя передала через Зоню й Марійку цукор і смалець для Вас. Думаємо, що певно з Вами $\epsilon$ брат з Грабовця з родиною. Можна передати ще що з річей. Напишіть чим скоріше! Цілуємо Вас дуже-дуже сердечно. Параска Дувір 12 квітня 1950 р. (автором швидме за все був Я. Сірецький-О. С.).

\section{До Верховної Ради УРСР у Києві.}

В тому міцному пересвідченні, що моє довір'я мене не заведе, звертаюся до Вас 3 проханням розглянути прихильно мою справу. Згідно з ухвалою Міністерства про переселення мене 3 родиною перевезли 31 березня на пересилочний пункт м. Коломия, тюрма № 2. Дозволю собі навести ряд причин, як промовляють за ухиленням від мене того вироку. Вони слідуючі:

\footnotetext{
${ }^{2}$ Коляструк О. Документи особового походження як джерела з історії повсякденності. Украӥнський історичний журнал. 2008. № 2. С. 146.

${ }^{3}$ Там само. С. 151.
} 
1) Я з дружиною находимося в тому віці, що вже ніяк не можемо загрожувати публічній безпеці (мій рік народження 1881, жінки 1883) і дбаємо тільки проте щоб якось спокійно дожити ще тих кілька хвиль життя.

2) Від кількох літ я важко нездужаю язвою желудка, артеріосклерозом та грудною жабою і перебуваю на лікувальному режимі. Лікарі заборонили мені строго всякого умового й фізичного труду. Від 1946 р. вслід за комісійним лікарським зреченням - після лікування в госпіталі не сповняю своїх станових обов'язків.

3) В минулому році, літом, наслідок надмірної праці та журби моя дружина занедужала важким круйозним запаленням легенів і від того часу іiі життя держиться що так скажу на ниточці. Потребує великого догляду й вигоди.

4) 3 молодших, моя дочка рівнож минулого року перейшла важку операцію, що також сильно підірвало іï здоровля.

Самі бачите, що ми не в силі перебути трудів переселення і воно в наших умовинах рівнозначне зі смертю, так що ми напевно не доїдем на місце призначення.

5) Думаю, що для Вас вповні достовірними будуть мої запевнення про брак усяких нелояльних чи антидержавних зв'язків по стороні всієї моєї рідні. Ми ніколи не мали й зараз не маємо нікого за границею ані в тюрмі ніхто з нас ніколи не був караний арештом радянської влади. 3 усіх зобов'язань супроти держави вивязування своєчасно й правильно. Про правдивість моїх зізнань може посвідчити Сіль-Рада с. Молодятин (Печеніжинського району, Станіславської обл. де я проживав) і секретар Райвиконкому Боровик.

6) Мій син Любомир весь час займався веденням хазяйства і працею дома (бо нікого більше до помочі ми не мали)

Я вповні свідомий цего, що радянський закон - найсправедливіший у світі закон, що все стоїть на сторожі прав людини і громадянина і ніколи не дозволяє кривдити безневинних і вповні переконаний, що Ви й цим разом - як завсігди станете на захист духа того високогуманного совітського закону.

Вслід за повищим, прохаю ухилити від мене й моєї сім'ї вище названий вирок.

Остаю з глибокою пошаною, Сірецький Антін Маркелович, священик

Коломия (с. Молодятин, р-н Печеніжин)

К. тюрма № 2

Дня 17. IV 50

Арк. 2, 2 3в, 3, 3 зв

Слава Ісусу Христу 18. 4. 50

Найдорожчі!

До Вас дуже важко передати листа хоч цілими днями наші сидять там під мурами. Якось частіше та більше приходить відти чим туди... Якось безнадійно. Кажуть, що тепер на вісім днів приїхала якась комісія і весь той час годі буде бачитися. Тут є дівч. з Гош. (Гомева) і якось частіше та менше комунікуються з о. Колодієм. Питайте його як він це робить, може там кому всунути що в руку. Той, що хліб возить, кажуть, може щось зробити. Пробуйте на всі лади. Також приготованих 500 крб. важко передати. Не дивуйтеся, ми стараємося скільки сил. Пішли вже дві заяви до Києва і Москви, ще три передав я до комітету щоб там потвердили ваш підпис... скоро довідаєтеся.

Арк. 4

Христос воскрес!

Найдорожчі!

Пишемо листи, декотрий зайде, бо дуже важко передати. Якось дуже добре радить собі о. Колодій з Гош. Тут $є$ дівчата з Г. Питайте його хто йому помагає. Чи той, що хліб возить, ті що замітають чи які там роблять роботи. Чи є там які згадки про См. (прізвище з'ясувати не вдалося) ? Недавно пустили Сір. Льва з родиною після три тижн. побуту в Богор. на таку заяву як я писав до Києва і Москви. Моліться і сильно вірте, що все ще може бути добре. Нічим не 
гризіться. Зоня 3 ... були вже два рази і хотіли бачитись. Годі було. Вони всі здорові. Вин. (Buнявські) ще в Стан. ... татові передасть нові черевики. Опишіть в що Ви всі повбирані і які річи взяли $з$ собою, щоби знати, що ще треба передати. I без того пишіть самі чого потрібно зараз постараємо. Чи всі Ви здорові весь час? Я написав ще дві заяви до Верховної Ради в Київ і Москву і до Станиславова як писав Любомир. Чи вже засудж.?.. Це конче треба знати.

Дуже сердечно цілуємо Вас.

Старайтеся відписати зараз бо відповіді ждуть. Все давайте може б хто в середину кидав або хай спитається чи є хто з Печ. (Печеніжина) чи Кол. (Коломийського) р-ну?

Арк. 5

Христос Воскрес!

Наші найдорожчі! Вітаємо Вас сердечно, завдячуєм за все добре! За давнє і теперішнє. Хай Г.Б. Вами опікується та кріпить ... не опустить. ...Тішимося як отримаємо лист від вас... Я тут сиділа тиждень щоб хоч трохи щось про вас дізнатися бо почтою вже ми писали. Мені було дуже прикро, що не передалися передачі з Дувір. (прізвище з'ясувати не вдалося) ... Я тут буду до середи бо боюся щоб Ви не від'їхали, що б ми не знали. Може Ви знаєте коли маєте виїзджати то напишіть. ... Ми отримали лист дуже докладний, листівки. ... Тато поїхали в четвер до Ст. ... Він сказав, що їхали до центрального комітету. Я говорила з Михайлюк з Мол. (Молодятина) просили щоб вона помогла... Може Г. Б. (абревіатуру з'ясувати не вдалося) поможе і як маю надію щоби Вас ще скоро не взяли може би Ви робили просьбу до Н. (прізвище з'ясувати не вдалося).

Здоровимо сердечно С. Ю.

Арк 6, 6 зв.

Найдорожчі! 17. 04.50

(Рік як ми були в Києві і милися в Дніпрі)

Досі дістали ми два письма. Я писав уже раз почтою, але може не доходить. Слава Богу, що добре чуєтеся. Я висл. вже дві заяви до Києва і Москви. До Києва ще крім почти мала окремо вести одна пані. До Моск. передав ще три подання з окремими характеристиками, щоби там переписали і все інше доповнити. Чи схоплять, побачимо. Коли б ні, вишлю без того. Все іде “авіа", коби Бог благословив, то може не забариться. У Вашій ролі були від 16 03. стрий Лев з рідними і ... перед пару днями їх пустили, тепер живуть у Стан. Виняв. ще там. Зоня з Мар. були вперше тут на шутк. неділю, вдруге вчера. Дуже хотіли побачитися з вами але не могли добитися дозволу. Дуже серд. співчувають і богато помагають Пш. (прізвище з'ясувати не вдалося), обі Юльці, обі Дув., Григ., Друзяка і інші. Я вже знайшов Унечці мешти і завтра дам. Так писати і висилати можете якнайчастіше, лиш оглядно. Я здоровий. Нічим прошу не журитися, особливо тим, що поза Вами й Вашими спроможностями... Божа воля над всіма нами най буде лиш так як Бог схоче. Мені в порівн. з Вами ще дуже добре і здорово. ... Конче напишіть, що Вам Всім найб. потрібне з річей, може таких що $є$, або щось докупив би чи ті річи забирають, що тепер передаєтеся? Що з харчів Вам найб. побажане? Чи Вас вже переслухали всіх? Чи був який вирок? Що з Люб. док.? Чи Муха (Мухою (Мамухою) діти називали маму Соpiю) весь час здорова? і тато та Всі? Я вже пару днів передаю Вам 500 крб. і годі Вам дати.

... Тета куди ходить плаче і молиться. ... Чи мною хтось цікав.? або тепер ще може? В якій формі? Чи Вам то не шкодить? ... Може Татові дати нові черев.? Що Л. має на ногах? Що Муха? Може би вшити на пам'ять суконку з моєї мат., що від Зоні. За Вас було вже 10 Сл. Б. ...

Дуже серд. цілуємо Всіх Вас і від всіх шлемо щирий привіт

Арк 7, 7 зв.

Хр. В.! Вчора дістали листа 319 04. Щире та серд. привітання Всім! Богато $з$ того, про що пише Л. я вже зробив. Був і в Б. (ім'я з'ясувати не вдалося), але вони ні в 3. (ім'я з'ясувати не вдалося) не були 3 листом ні в Тр. (прізвище з'ясувати не вдалося) зате в Тр. я був сам і чув (“інстикттивно”...) що вони не збираються нічого помагати тай ледве чи зміг би що. Всі ка- 
жуть, що може помогла би фльота в тім ... треба ще ії мати. ... См. заявив прямо і щиро, що боїться подібно і другий Дост. і Друзяка “годиться" але аж тоді як друзі те зроблять... Там спішно ходять попід саму хату та змагаються за город школа з комсомолом... Ті всі письма хочемо післати тепер зовсім приватно від когось з родичів. ... Мешти далося тому дістати ... може і більші добрі підуть для Мухи, або й для У. то прошу собі лишити, а як дозволять передати якось "опять" на волю (але це не конечне). У Гу-гу і Б. тверд. що треба конче підп. і все буде добре... без клопоту. Святк. перший день в Кол., другий в Ст., а третій знов у Кол. ...

Чи нема там з вами тут вікарія? ...Що можна куп. в тім склепі? Купуйте там масло, каже Б. що є по 40 крб. щоби все його мали. Десь в найближчих днях надамо для Вас 100 крб. бо кажуть, що жадних відгуків на інтервенції? Були і в дні і ін. там. I може ще будемо в потребі. Черевики вже взяли від П. і постараємося дати може разом з Белляд. (прізвище з'ясувати не вдалося) та ше ..ко лиш можна. Пар. (прізвище з'ясувати не вдалося) і Д. (ім'я з'ясувати не вдалося) щось хора, дуже зле вигл. Нині в Карпин. гостить Пелов., завтра тут “візит”. .. Потім певно разом з вус. пішлють сльозоточивого листа та зо 100 крб. грошам...

Чи нема там Петр. з Граб.? Чи не чули від кого де Котл. (Котлярчук)? Нічого не відписує на лист... Вам щось читати, богато розряди мали б Ви з газет. У справі шпит. лікув. добре подумайте бо коби знов не розлучитись через то.

Пишіть найшв. і найчастіше про все, а особливо про всі свої потреби.

Дуже сердечно Всіх цілуємо

26. 04. 50

Арк 8, 8 зв.

Прийомна Голови президії Верховної Ради Української РСР 26 квітня 1950 р. м. Київ вул. Кірова № 4.

гр. Сірецький А. М.

Повідомляємо, що Ваша заява одержана і надіслана на розгляд виконкому Станіславської обласної Ради депутатів трудящих з проханням про наслідки Вас повідомити

Завідуючий Прийомною О. Носенко

Арк 9

Насамкінець зазначимо, що родину Сірецьких (самого отця Антіна, їмость Софію, сина Любомира та дочку Марію) у травні 1950 р. було таки депортовано на Далекий схід, в Хабаровський край, де впродовж чотирнадцяти років їм доводилося приймати виклики суворої доби. Водночас, молодший син Антіна Сірецького, підпільний священник Ярослав Сірецький, дивом уник арешту і заслання у 1950 р., залишився підпільно священнодіяти на території тодішньої Станіславської області. Отця Ярослава Сірецького було арештовано радянськими спецслужбами лише у березні 1957 р. у Коломиї.

\section{REFERENSES}

Koliastruk, O. 2008. Dokumenty osobovoho pokhodzhennia yak dzherela z istorii povsiakdennosti. Ukrainskyi istorychnyi zhurnal, no. 2, pp. 145, 146, 153 (in Ukrainian). 